\title{
Perspectives Perspectives
}

This section features: (1) reactions of readers to articles and reviews published in the Journal and the replies of authors to whom the comments are addressed (if forthcoming) and (2) viewpoints and opinions expressed in the form of a report, commentary, or interview on issues or topics of current interest.
Cette section sera consacrée à deux types d'articles:

1. La réaction des lecteurs aux articles parus dans la revue et la réponse de leurs auteurs, sil y a lieu.

2. Les points de vue et les opinions, présentés sous forme de comptes rendus, de commentaires, de chroniques ou d'entrevues, sur des sujets d'actualité ou d'intérêt général.

\section{SOME THOUGHTS ON PRACTICE, POLICY, THEORY AND RESEARCH IN LANGUAGE TEACHING: A CONVERSATION WITH H.H. STERN}

\section{Alister Cumming}

\section{Cumming:}

How do you see teachers' personal theories of language teaching relating to the theories of academic studies of language education?

\section{Stern:}

I think they are very closely interrelated. It seems to me that policymakers, administrators and practicing teachers all have some sort of theory of language teaching. If you ask me what that theory is, I would say that it is really the underlying value judgements or the philosophy they entertain. It need not be verbalized; it is likely to be implicit in their actions.

For a professional, it is a very useful thing to be able to identify what in fact his or her views are on essential issues. I have tried to prepare a kind of guide for doing that in my recent book Fundamental Concepts of Language Teaching (Stern, 1983). A teacher should be able to identify, from an existential point of view, where he or she stands within the historical movement of language teaching. That, it seems to me, is one essential issue. 
The others are how we view four basic concepts - language, social context, learning, and teaching. Everybody must have, somehow, some sort of view of these. They make up a teachers' underlying theory, or philosophy if you like. Obviously, that theory would be subject to change on the basis of one's own personal experience, as well as on the basis of the further developments in thought and research.

\section{C: Why then do you think there have been so many disputes over the relations} between practice and theory in language teaching?

S: My answer lies in what I describe as two fallacies that we tend to be prone to make in language teaching. One of them is the single-factor fallacy, which is to say that a single factor is thought to be allimportant. It is all right for a researcher to focus on one thing at a time, but if you are involved in teaching, you can't be concerned with just one single factor. In language teaching there is always a multiplicity of factors that have to be taken into account. You may not always emphasize all of these, but you should be open to them. I see the single-factor fallacy most clearly in the 'method-battles', where a single factor is often over-emphasized.

The other thing that is often confused is the relationship between theory, policy, and actual classroom practice. I have sometimes described that as the 'level confusion'. If one thinks of three levels bottom, middle, and top - I see at the bottom level the sort of philosophy that is entertained. The middle level I would regard as the policy level. The top level I would see as the level of practice or classroom action. The level confusion is that you think you can mix them with impunity or that you assume there is only, say, the classroom level, and the rest is not important or real. People who think in these terms imagine that researchers expect them to remember 'what research says' while they are in the process of teaching. That's ridiculous. That seems to me to be a confusion of levels because while you teach, you act intuitively, your philosophy is already in place, and you simply act it out. You can't modify it or change it - just as little as you can change policy as you actually teach in a classroom. You have to make your change of policy by going down from the action level at the top to the middle level.

Or, take the policy level: there are certain things we don't know. For example, what is the best age to start studying a language? You have to go down to the basic level of research and theory. That is a very legitimate thing to do. But what I would call a 'level confusion' is that when you are trying to make a policy decision, at that point you can't do first-hand research. You couldn't, for example, at the policy level, 
ask the researcher, at what age should we start to teach a language? At that point you must have made up your mind about the optimal age for learning a language. You can't, then, suddenly start searching around to find out what the optimal age is. That must, by that time, be clear. If you have come to the conclusion that we don't know or there isn't an optimal age, then you have to arrange your policy accordingly.

You can't mix these levels up too much. I feel this tends to be done, and I think that by not making these distinctions a good many disputes arise. But if you do make these distinctions, you can see that each of these levels has its legitimate functions to fulfill and can be helpful to the solution of problems at the policy level and even at the practice level.

C: You are distinguishing between the intuitive processes of teaching and the acts of reflecting on, planning for, or thinking about these processes. Do you think this distinction is a problem?

S: I think it's a problem but not an insoluble one. It becomes a real problem for teachers while they are on their feet and have to make decisions. At that point, they can't be overly reflective. That's impossible. It doesn't mean that teachers have to be thoughtless but that their planning often is, after all, spur-of-the-moment planning and must also be adjustable. The practicing teacher who goes into a classroom with a lesson plan made up beforehand has engaged in a middle-level kind of planning or policy activity. When that teacher goes into the classroom, he or she will obviously want to act out the plan — but he or she must also be responsive to the situation. If the plan doesn't work, the teacher ought to be able to adjust it there and then.

But then you may still, after you have taught your lesson, stand back and say, now, for future reference what does that mean in terms of overall planning of my course? These teachers can do a great deal of meaningful planning, thinking, and readjusting. I think that needs doing. I see there's a sort of interplay between the planning function and the actual teaching function. But you need some definite concepts to be able to be analytical about your teaching.

C: You then see teachers' theorizing as informing their teaching practice?

$S: \quad$ That's right. Your theory should inform your policy or planning, which then should also inform your practice. Your practice should be done on the basis of what you have previously thought out, not mechanically, but flexibly and adaptively. It should be done on the basis of your previous thought, which in turn goes back to some theorizing. I think this has some bearing on teacher education, because 
in teacher-training, you should have the opportunity to do this kind of preliminary thinking. In initial teacher education, one shouldn't make things too complex. The options or reasons that are presented should be relatively simple because one is still 'learning the trade' so to speak. But experienced teachers also need time for reflection. They should be able to review their policy as well as go back to the more basic, philosophical level.

C: It has been said that teachers need a theory more than they need textbooks, materials, or other forms of programmed study. What is your opinion of this view?

S: I find that an excessive statement. To me, a teacher needs theories, all right, because they help to select the right kind of learning materials and to learn from one's experiences. But I think the expectation that teachers should, out of their own resources, develop everything is too extreme, especially for very busy teachers. Many teachers are very fully occupied actually teaching, working with classes, day in day out, from morning until afternoon. Teaching is often a non-stop operation. Obviously if the circumstances are well handled, there will be periods of time for preparation, reflection and rest. But even then, there is not usually a lot of time. Since teachers are fully occupied like that, they must be able to draw on materials or other resources. Obviously such materials are not 'ready-made' in the sense that they are immediately or perfectly adjusted to any particular group of students. Therefore, that's where the teacher's own initiative and skill has to come in - to make the necessary judgements and adjustments. It is certainly essential to do that.

Teachers need the support of resources which are put at their disposal. They need the support of a program, ideally a program they like and feel comfortable with. Obviously if the program is bad, that is, it conflicts with their basic philosophy, it can be hard going, painful and disheartening. In that case, it is better to be without one.

C: Do you consider research to be essential to language teaching?

S: Yes, I would not like to think of any kind of language teaching reforms or improvements nowadays without their having a research component. I am critical of the recent methodological 'experiments' Counseling Learning, the Silent Way, Suggestopedia, etc. - that are so widely advocated in the United States. Admittedly, they have important messages for language teaching, but they are inadequately supported by sympathetic but sound research. Asher does research on the Total Physical Response, but he himself is the advocate of the method. 
There must be other people who look into a new method without such a close identification with it. I don't think it can be expected of someone to be a reformer and to be a researcher of that reform at the same time. Somehow there must be a separation of functions, but such research should be done.

I went to conference in New York recently where these 'new methods' were discussed in great detail and very patiently. They had the right people there who knew the methods from the inside. But it seemed to me that the audience who were very sympathetic to these new methods were rather negative about any research. Michael Long argued the case for empirical research to be done on these methods. I agreed with that. I felt exactly the same way - that there should be more research. But the reaction nof the people in the discussion was that they were afraid that researchers would merely be there to find fault and to discredit the new methods. I don't think that the appropriate attitude for a researcher to take would be merely criticize. A researcher should take a sympathetic view of an innovation but, at the same time, take a more global, detached position than the person who is actually practicing and advocating it.

C: The view has also been expressed that language teaching has at times been over-influenced by research results.

S: There is a fear that the researcher comes along and makes statements, on the basis of certain studies, which more or less bind teachers in some ways. But I feel that, if a distinction is made between the levels of teaching, policy, and research, and people ask themselves what the effect of research is on policy and classroom practice, there are sufficient steps between the actual research and classroom practice providing the necessary safeguards. I can see, though, that this has happened. Sometimes linguistic research or psycholinguistic research have had the effect of being thought of as being thought of as being too directly applicable to what occurs in the classroom. In such cases, the research could be negative in its effects. But I think that probably arises from a misunderstanding about the place and role of research.

Of course, there is a different emphasis on policy and research in different parts of the world. North America has been rather favourable to empirical research. In Britain, and I think in Europe generally, there is greater interest in theory - thinking about language teaching than in empirical research. I have found that in Britain empirical research tends to be somewhat looked down upon - as being dangerous, unnecessary, or even misleading. I don't have that fear of empirical research. I agree that empirical research without thought is 
absolutely useless. There is obviously a lot of collecting of data which is meaningless - that's just poor research. But I don't think that's a valid criticism of research in general.

For example, in the study that we are currently doing on Core French (Stern, 1985) in Canada, we are very insistent on new curriculum ideas. These have to be tried out in classes; that's the sort of empirical test. But I wouldn't be happy if they were merely tried out in the sense of, "Oh yes, it works" - that someone tells us these ideas work. I would like to have them more empirically verified by classroom observation, by a certain amount of testing, by questionnaires to teachers and students, or by interviews. Therefore, a systematic inquiry should be associated with these experiments. I think that is important. I would not like that to be dismissed. Extensive evaluation may not always be possible in curriculum development, but I would ideally like to see it take place.

I have been getting more and more critical of research that exclusively involves testing, which I think is too narrowly focused. I would be in agreement with someone who criticizes it, but not because it's research, but for the reason that research is too narrow.

However, I have also criticized much of what is now called "classroom-oriented research" because it is similarly often too narrowly focused. It often involves just counting things without a theory underlying the research. The classroom is observed without understanding, first of all, what the underlying intention is on the part of the teacher or the course. It's like dropping in on a conversation; one can't always make sense of it. Similarly, being able to make minute observations does not necessarily mean you find out very much. But these are qualitative differences between different types of research. One can argue about which is the best kind of research to do in particular circumstances. But, in principle, I am very much in favour of having some kind of research component with curriculum innovations as part of their evaluation.

C: You have been critical of the concept of methods of language and the many changes in the status of methods over time.

S: I have certainly criticized the rapid 'turn over' of methods this century. I really came to the conclusion that the narrow concept of the 'method' was over by the early 1970s. This is why the so-called 'new methods', such as Suggestopedia, etc., came to me as a great surprise. If somebody had asked in 1970, "Do you think there will be a lot of new methods?", I would have predicted, "No, that's finished with. The audio-lingual/cognitive battle was the last one." I didn't think of 
communicative language teaching as a method in that sense. I thought of it as a broader development that couldn't be described in any narrow sense as a method.

\section{C: Do you consider the notion of theory we were discussing earlier as a kind of counter-balance to the notion of methods?}

S: Yes, I do. A theory of language teaching, as I see it, is wider than any one method. A theory includes a broader range of options, partly because it is multi-conceptual. Most of the methods have been very uni-conceptual. Also, language teaching has moved away from being based on a single discipline or one single approach, for example, to linguistics or psychology. For most language teachers, there must be a sufficiently broad basis of theory to inform their thinking and actions than a single prescription can offer.

I am ambivalent even about the Natural Approach (Krashen and Terrell, 1983), although I think it is very carefully thought out. It's very interesting; I see its merits; I have a sneaking liking for it. But I could never firmly associate myself with it. I could not say I am an advocate of the Natural Approach, mainly because I do like to have a wider range of options. I feel that our theory can be formulated in such a way that teachers have a wider range of options. Committing ourselves to one approach boxes us in. Then teachers have to accommodate themselves so much to situations which were not thought of in the first place, or they have to abandon the theory altogether, which is not a very good thing either. This is why I was not really happy about the 'method boom' of the seventies. I thought we could have a broader, more professional approach to language teaching which is not so limited in its handling of issues. These limited solutions have been a weakness over the past 20 or 30 years. We have restricted ourselves too narrowly, causing us unnecessary struggles.

C: I thought you might have been more sympathetic toward the Natural Approach.

S: It is very persuasiave and well worked out. It has an important message: learning a language through communication. But it is, as I said, just too limiting. To my mind it is too sanguine about pronunciation and grammar. Even the injunction of comprehension before speaking is problematic. There had been a tendency for teachers to press students to speak when it was perhaps premature. But to move in the other direction - of saying, now don't speak - is in itself another new injunction which can be very stultifying and even misleading to 
students who would like, or need, to speak. I find this way of handling things unfortunate.

$\mathrm{C}$ : How then do you view the changes which have taken place in language teaching?

S: You get a better perspective if you look at this question historically. In 1882, a famous pamphlet was published with the title of "Language Teaching Must Make an About-turn" (Vietor, 1882). I recently asked myself: are we in the same situation today? Do we say today that language teaching must break with its immediate past? My answer to that question was no. I think that there has been much more continuity in the development of language pedagogy in recent years. Therefore, there must be some valuable things which have been achieved over time and we don't need today a complete break with the past.

C: The relation between theory and language teaching has clearly been a long-standing interest of your.

S: Really it goes back to the early 1970 s, partly out of the confusion that arose over the roles of linguistics and psychology in relation to language teaching. I was concerned about it at that time, as a number of other people were - for example, J.B. Carroll (1971), Wilga Rivers (1972). I especially remember a paper by Ron Wardhaugh (1969), who was very strongly conscious of this. This controversy caused me to look more carefully into the whole question of the roles of the academic disciplines in relation to language teaching, and this has largely prompted the book I referred to earlier (Stern, 1983).

There are certain stages in which my thoughts on this have developed during the seventies. One was a paper I wrote for AILA in 1972 in Copenhagen (Stern, 1974), which was a plenary address on the subject of theory and research in second language teaching. Then there was a second long paper I prepared jointly with Mari Wesche and Birgit Harley (1978), also on the relationship between these disciplines and language teaching as an example of the impact of educational research on language teaching. That was part of a larger project organized by the National Academy of Education in the United States. People wondered whether research was really all that beneficial to the advancement of education. That paper served, in some ways, as a trial run for what was later developed in greater detail in my 1983 book, in my lecture courses at OISE, and the book on methodology, I am working on at present. 


\section{ENDNOTE}

1. H.H. Stern is Professor Emeritus in the Department of Curriculum of the Ontario Institute for Studies in Education (OISE), University of Toronto, and a Killam Research Fellow (1982-1986). He was the founding director of the Modern Language Centre at OISE, a position he held from 1968-1981. He now works as a freelance language consultant, author, and lecturer and is currently directing the Canadian Association of Second Language Teachers (CASLT) National Core French Study.

\section{REFERENCES}

Carroll, J.B. (1971). Current issues in psycholinguistics and second language teaching. TESOL Quarterly, 5, 101-114.

Krashen, S.D. and Terrell, T. (1983). The natural approach. San Francisco: Alemany Press.

Long, M.H. (1984). Process and product in ESL program evaluation. TESOL Quarterly, 18, 409-425.

Rivers, W.M. (1972). The foreign language teacher and cognitive psychology, or where do we go from here? Rpt. in Rivers, W.M. (1976). Speaking in many tongues. Rowley, Mass: Newbury House.

Stern, H.H. (1972). Directions in language teaching theory and research. In J. Qvistgard, H. Schwarz, and H. Spang-Hanssen (Eds.), Applied linguistics: problems and solutions, Vol. 3 of the Proceedings of the AILA Third Congress, Copenhagen, 1972. Heidelberg: Julius Groos Verlag, 1974, 61-108.

Stern, H.H. (1983). Fundamental concepts of language teaching. Oxford: Oxford University Press.

Stern, H.H. (1985). Movements, projects, and core French today. Canadian Modern Language Review, 42, 324-341.

Stern, H.H., Wesche, M.B. and Harley, B. (1978). The impact of the language sciences on second-language education. In P. Suppes (Ed.) Impact of research on education: some case studies. Washington, D.C.: National Academy of Education, 397-475.

Vietor, W. (1882). Der sprachunterricht muss umkehren! Ein beitrag zur überbürdungsfrage. Heilbronn.

Wardhaugh, R. (1969). TESOL: Current problems and classroom practices. TESOL Quarterly, 3, 105-116.

\section{THE AUTHOR}

Alister Cumming, who conducted this interview, is presently a Ph.D. candidate at O.I.S.E., where he has also been working as a research officer in the Educational Evaluation Centre. 